\title{
ANALYSES OF STRUCTURE PHASE STABILITY OF U-Mo TARGET OF THE NEUTRON SOURCE
}

\section{B.V. Borts, I.N. Laptev, A.A. Parkhomenko, A.F. Vanzha, I.A. Vorobjev, Yu.A. Marchenko National Science Center "Kharkov Institute of Physics and Technology", Kharkiv, Ukraine E-mail:parkhomenko@kipt.kharkov.ua}

The paper presents analyses of structure phase stability of fuel materials by means of phase diagrams of martensite transformation method, proposed earlier for the system of "iron-carbon-vacancy". It was shown that role of molybdenum in stabilization of uranium gamma-structure under irradiation is to hinder of the phase to phase transformations of martensite type. The role of point defects and electron structure in the process of homogenization of alloy structure in the process of irradiation was studied.

\section{INTRODUCTION}

Creation in NSC KIPT, mutually with Argone National Laboratory, USA, of the subcritical assembly, driven by electron accelerator $100 \mathrm{MeV}$, as the prototype 5-th generation of nuclear reactors [1] is one of the most important scientific projects which are under realization in Ukraine.

Use of uranium with molybdenum alloys, which maintain in the wide range of temperatures the isotropic volume-centered cubic lattice of high-temperature uranium $\gamma$-phase, highly resistant to irradiation influence [2, 3], constitutes the solution to increase metallurgical and radiation resistance of uranium target of the neutron source (NS).

Taking into account that one of the variants of the NS target material in uranium-molybdenum alloy $(7 . .10 \% \mathrm{Mo})$, it is necessary to perform analyses of structure phase stability in conditions, corresponding to NS operating parameters, that is under relatively low target temperatures (not more than $100{ }^{\circ} \mathrm{C}$ ) and integral neutron fluxes (about $10^{19} \mathrm{n} / \mathrm{cm}^{2}$ ), mainly of the thermal spectrum.

Transformations of martensite type [4, 5] play an important role in formation of structures in reactor materials under irradiation - in uranium, zirconium, structural steels. As the analyses shows, alloys with 9, 10.5 , and $13.5 \%$ Mo, irradiated under mentioned above parameters, are subject to phase transformation of martensite type under irradiation from $\alpha$-modification with rhomb lattice into meta-stable high-temperature modification of $\gamma$-uranium with cubic lattice, with alloy homogenization attendant to this transformation. In the initial state it constituted eutectoid: particles of intermetallide $\mathrm{U}_{2} \mathrm{Mo}$ (gamma grove-phase) were dispersed in alpha-uranium matrix.

After irradiation the alloy constituted homogenous solid solution based on the gamma-uranium. It means that, impact of low-temperature low dose irradiation was similar to influence of heating of this alloy to temperature above $771{ }^{\circ} \mathrm{C}[6,7]$. Despite several decays of research of this alloy the nature of this effect remains unclarified in full. This is confirmed by recent mutual research of specialists from the USA and China [8].

This paper is aimed at checking the possibility to use the developed earlier by authors method of phase diagram of martensite transformation (MFDMT) [4, 5], to study the structure phase stability of uranium and uranium-molybdenum alloy, and also determination of molybdenum role in stabilization of uranium gammastructure under irradiation.

\section{HYSTERESIS LOOP OF PHASE TRANSFORMATION IN URANIUM}

Initially the hysteresis loop of FCC-BBC transformations was constructed without reference to any particular metal or alloy. That is why, answer on the question - whether our assumptions on the existence of hysteresis loops under phase transformations in the systems other than iron are correct was very important for us. Uranium constitutes particular interest from this point of view. In pure uranium the high-temperature $\gamma$-phase has BBC lattice, but phase changes in it in the process of cooling do not result in appearance of FCCstructure. Uranium lattice turns into tetragonal below $771^{\circ} \mathrm{C}$. However, in BCT - iron the ration is $c / a>1$, in uranium it is $c / a<1$. It means that crystallographic BCT-cell of uranium has non-elongated, as in iron, but oblate from (Fig. 1) [9]. Below $668^{\circ} \mathrm{C}$, uranium lattice becomes orthorhombic, similar to drawn hexagonal. The cell of FCC lattice of iron is presented for comparison, and areas of BCT-structures in iron and uranium are presented. Fig. 4 indicates angles of cells deformation (from 35.25 to $25.88^{\circ}$ ).

Calculations and modeling demonstrated that hysteresis loops of phase transformations exist either in pure uranium or in iron (Fig. 2).

Defomations of the cells according to the scheme (see Fig. 1,d) and formulas, which were discovered for iron [4]. The difference is only that deformation angles, in the process of $\mathrm{BBC} \rightarrow \mathrm{BCT} \rightarrow \mathrm{OR}$ (orthorhombic phase) transformations, are changed in the limits from 35.25 to $25.88^{\circ}$. Similar to $\mathrm{BBC} \rightarrow \mathrm{BCT} \rightarrow \mathrm{FCC}$ transformations in iron, OR-structure (stable as $\mathrm{FCC}$ in iron) should be understood as final, to which certain tetragonality corresponds, equal approximately to $c / a=0.577$. In other words, if in iron $c / a$ changes from 1 to $\sqrt{2}$, in uranium it is 1 to $1 / \sqrt{3}$. Analyses of experimental meanings of uranium cell parameters demonstrated that both big parameters correspond to smaller in equal proportion with different authors: $a / b=0.489$, $a / c=0.576$ [9]. Almost full coincidence of experimental meaning of ratio $a / c=0.576$ and design value $c / a=$ 0.577 allows to make a conclusion that experimentally determined parameter $a$ of the orthorhombic structure, in fact, is the parameter $c$ of the drawn tetragonal lattice. 

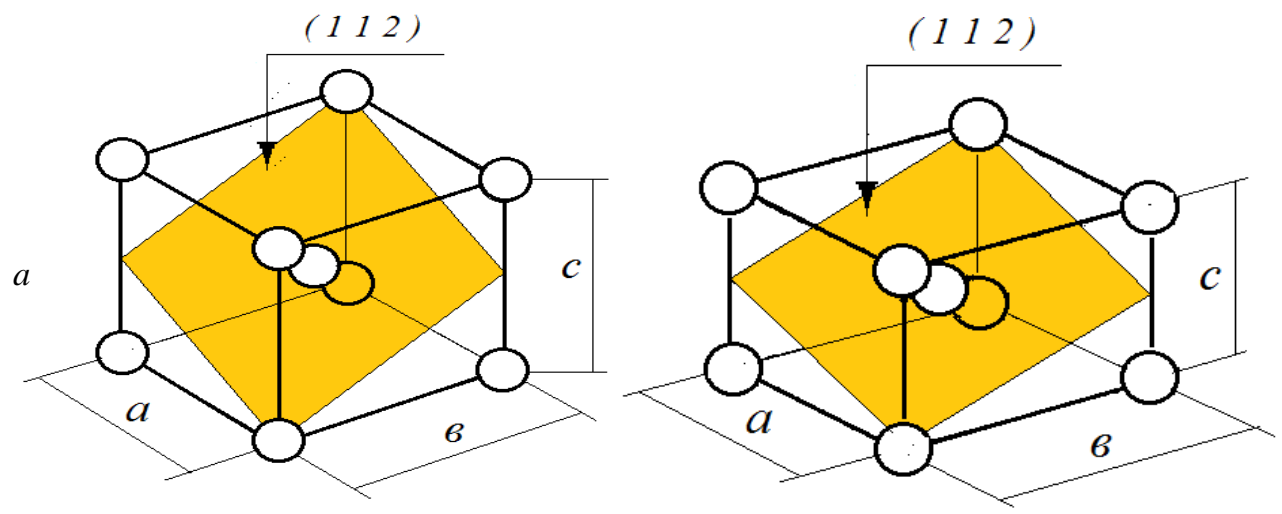

$b$
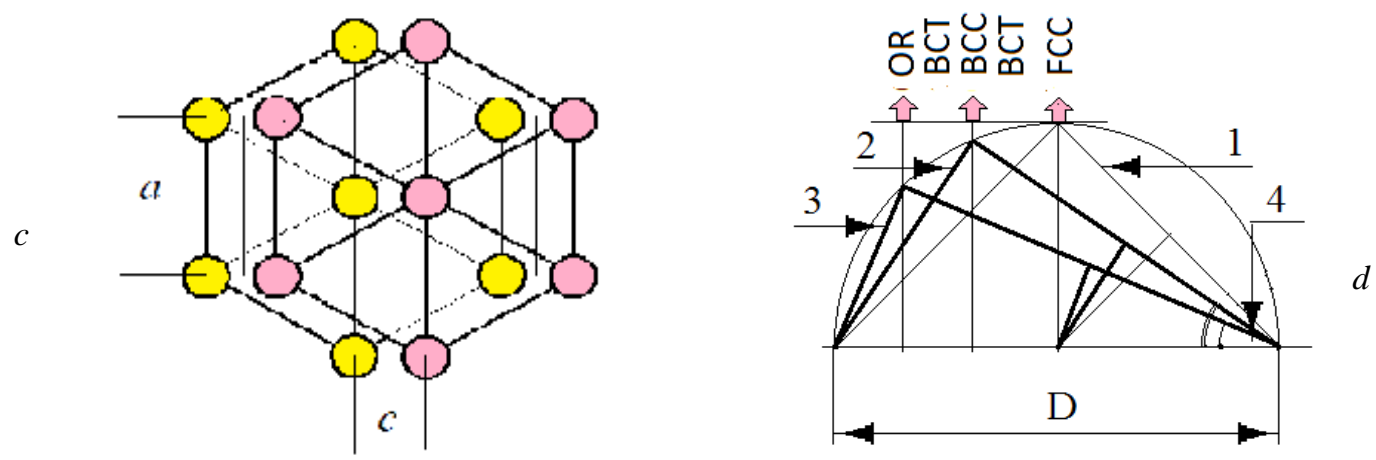

Fig. 1. Crystallographic cells of different phase states of uranium:

$a$-high-temperature BBC $\gamma$-phase, existing over $771^{\circ} C$; $b$-tetragonal $(a=b>c) \beta$-phase (BCT), existing under temperatures from $668{ }^{\circ} \mathrm{C}$ to $771{ }^{\circ} \mathrm{C}$; c-orthorhombic low-temperature $\alpha$-phase $(\mathrm{OR}) ; d$-deformation scheme of uranium lattice $(a=b=c)$ (indicated with Figs. 2 and 3 ) in the cooling process

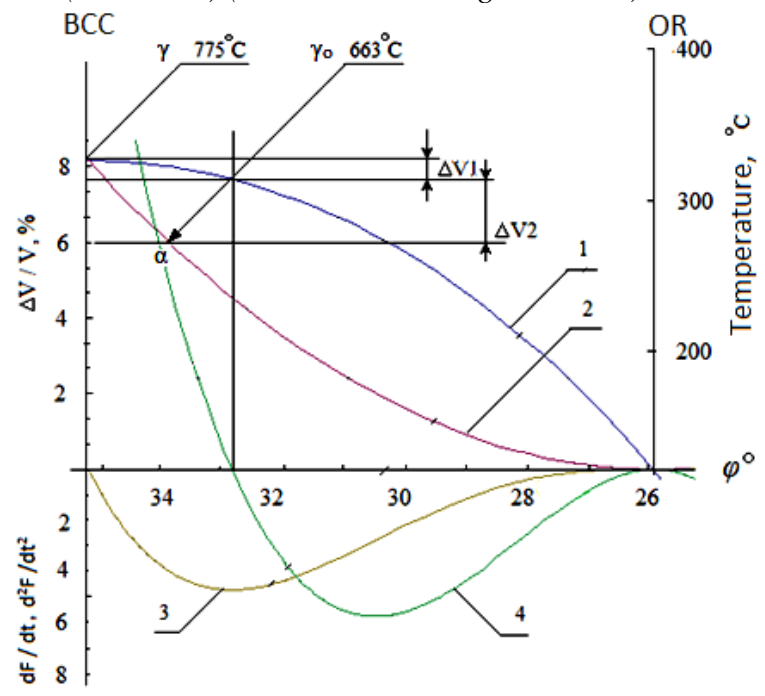

Fig. 2. Curves 1 and 2 -upper and lower branches of the loop; 3 and 4 -change of internal energy of the system under its deformation along the upper branch and its derivative, which determines the point of extremum (dimension scale is optional). $\Delta V / V$-volume relative change in the process of phase transformations, $\varphi$ - angle of elastic displacement of atoms in the process of transformation of structure from one phase conditions into another: $\triangle V 1$ - smooth changes of volume of the system in the cooling process (changes are performed by deformation along the upper branch of hysteresis loop on the angle equal approximately 2,5 \%, AV2-change of volume under unchanged temperature (growth of volume takes place due to isolation of martensite alpha-phase)

It should be marked specially, that in iron, direct martensite transformation $(\gamma \rightarrow \alpha)$ is performed with appearance of phase with density less than initial FCCphase. This process takes place under high cooling speed as demands in over-balanced concentration of vacancies.

In uranium, phase transformations pass with appearance of more solid $\beta$ - and $\alpha$-phases. Such processes do not need vacancies and can pass under 
slow cooling. In other words the $\beta$-phase is elastically drawn tetragonal $\gamma$-phase. Its formation is the smooth process caused, mainly, by well-ordered displacement of central atoms in BCT-structure [3]. This displacement takes place in parallel planes (200) in opposite directions $<100>,<100>$ up to extreme meaning of the energy system, which corresponds in our description, to the extremum in the hysteresis loop (see Fig. 2, curves 3 and 4).

Under such energy meaning the system looses stability - the shifting atom passes through deformation barrier and stepwise incorporates in to the plane (100) or (100). Thus $\alpha$-phase can form. Despite all differences, process of phase $\gamma \rightarrow \beta \rightarrow \alpha$ transformation, either like in iron, is collective, shearing and thus martensite.

\section{SYSTEM OF URANIUM-MOLYBDENUM}

According to the literary data, molybdenum in uranium behaves itself as the interstitial element. While dissolving in uranium, molybdenum atom (similar to carbon atom in iron) occupies the center of octahedron which forms two contiguous BBC cells [9]. Such [9] octahedron constitutes the elementary cell of $\mathrm{U}_{2} \mathrm{Mo}$ phase.

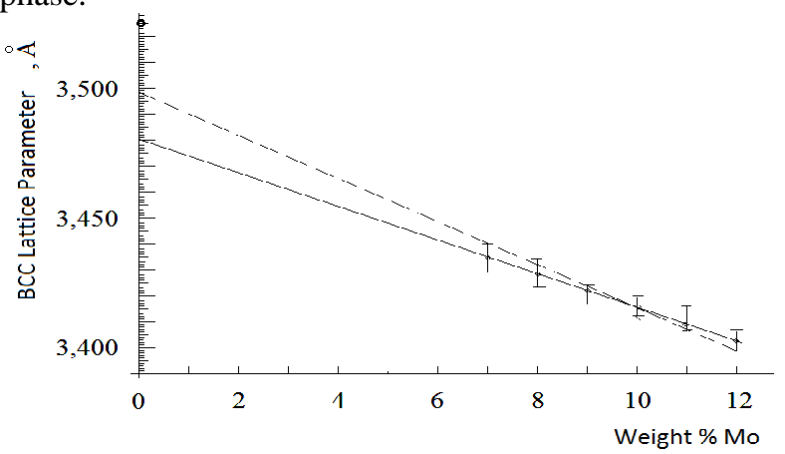

Fig. 3. Changes of BBC lattice parameter in the system $U$-Mo depending on content of Mo in uranium. Experimental data are taken from the paper [10]
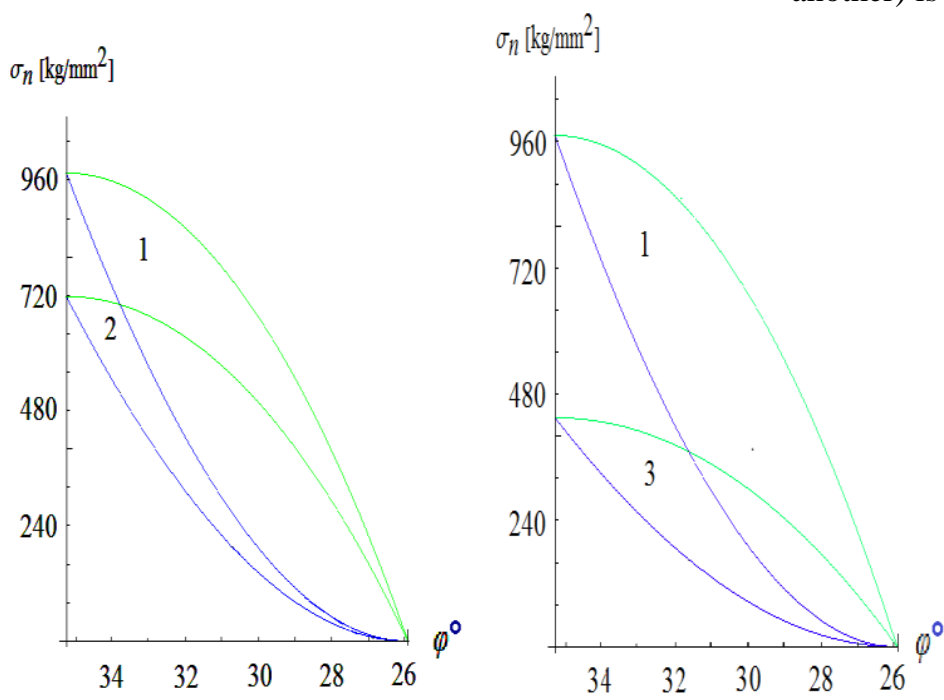

Fig. 4. Consistent deformation of the hysteresis loop in the system uranium-molybdenum:

1 - initial loop; 2, 3, 4-loops in the system U-Mo with molybdenum content 3, 6, 9 wt.\% of molybdenum, correspondingly. Calculations are performed for BBC parameter of uranium lattice equal to $3.500 A$
Elementary calculations witness that even under smallest inter-atom distance $(3.4 \AA$ in the alloy with $12 \%$ Mo, Fig. 3) in the center of octahedron, enough place is remained for free placement of molybdenum atom. (For reference: diameter of uranium atom $2.76 \AA$, diameter of free volume in the center of octahedron $3.14 \AA$, diameter of molybdenum atom $2.78 \AA$ ). Approximation for zero content of molybdenum presented in this paper and calculation of $\Delta V / V$ allows to perform estimation of change of the volume on each percent of molybdenum with value approximately equal to $0.55 \%$. In particular this effect of densification allows compensating the negative effect from decrease of enrichment on uranium-235, when developing compositions based on uranium-molybdenum for use in experimental and research reactors [2].

If molybdenum in uranium formed the substitution solution, then its influence would distribute on each cell of BBC lattice, or on 8 closest to it cells. It means that in the first case for stabilization of BBC-structure concentration of molybdenum about 50 at. $\%$ is needed, and in the second case - less 7 at.\%. When recalculating into weight percents it is, correspondingly 24 and $2.4 \%$.

As Mo atom, dissolving in uranium gets into the center of octahedron, formed with two cells, it should be supposed, that influence of molybdenum atom is spread only on these two cells (4 atoms). Based on this we can estimate the critical concentration of molybdenum, which should from the BBC-structure in the whole volume 100:4 $=25$ at. $\%$. In weight percents the optimal concentration of molybdenum in uranium will constitute: $25: 2.45=10.2$ wt. $\%$. This meaning is in good consent with experimental data, according to which U-10\% Mo alloy has the best combination of properties and is more stable thermodynamically, than for example U-7\%Mo alloy [11].

Changes of position of hysteresis loops in coordinates "normal stress $\sigma_{\mathrm{n}}-$ angle $\varphi$ " (angle $\varphi-$ characterizes elastic displacement of atoms in the process of restructuring from one phase condition into another) is presented on Fig. 4.

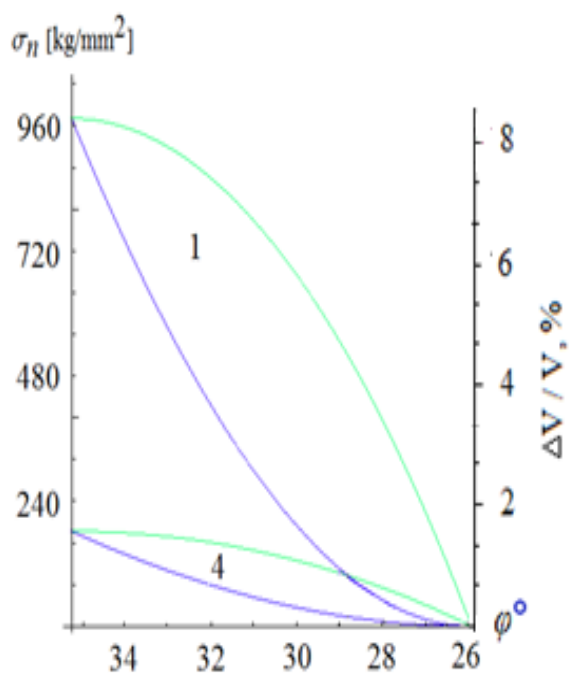


Taking into account, that positive direction of the ordinate axis corresponds to the growth of tensile stresses, the obtained results can be interpreted as growth of values of compressive stress under step-bystep increasing concentration of molybdenum from three to nine percent (Fig. 5).

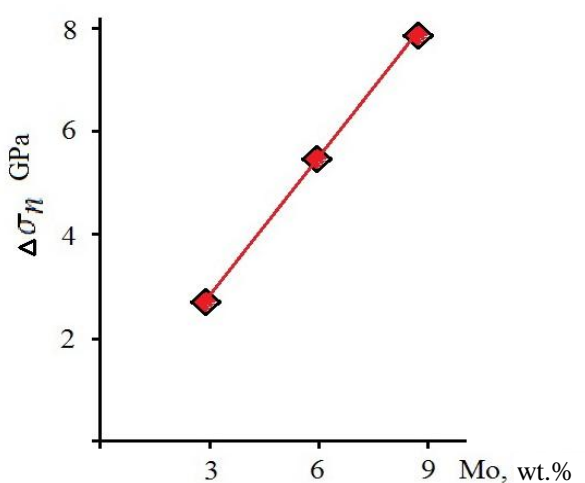

Fig. 5. Increase of compressive stresses in the process of alloying the uranium with molybdenum

Thus despite significant growth of compressive stress, reaching $8 \mathrm{GPa}$, uranium-molybdenum alloys retain the $\mathrm{BBC}$-lattice, which is confirmed by X-ray research [11]. As in the process of alloying of uranium with molybdenum hysteresis loops exist, which can be seen from Fig. 4, the martensite transformations under concentrations of molybdenum less than $10 \mathrm{wt} . \%$ also take place. At this the width of the hysteresis loop characterizes not only the stress value necessary for martensite transformation but also in the reverse proportion to molybdenum concentration, describes the corresponding volumes of transformations. Together with the growth of molybdenum concentration it describes the corresponding volumes of transformations. Width of the hysteresis loop (that is distance between lower and upper loop branches) decreases with the growth of molybdenum concentration and correspondingly decreases the value of specific volume of martensite transformation.

Similar to alloy $\mathrm{Fe}-\mathrm{C}$ (carbon in iron - interstitial impurity) [4, 12], decrease of transformation temperature (that is growth of transformation energy) in U-Mo system and decrease of specific volume of transformation with growth of concentration of alloying element take place.

\section{UNDER IRRADIATION}

It should be noted the processes of homogenization of the structure and composition of metals and alloys in non-equilibrium conditions (not only under irradiation) constitute the known fact. Thus, even particles of the cementite in alloy iron $-1 \%$ carbon, which do not decay under annealing temperature $900{ }^{\circ} \mathrm{C}$ in equilibrium conditions, are decayed under rolling deformation on $90 \%$, when high concentration of point defects appears in the material [13]. Formation of such defects in strained materials is still subject if intensive research (see review [14]). Under influence of irradiation process of homogenization can result in the following - initially fragile fuel became more plastic under irradiation influence $[15,16]$.

Homogenization can be resulted from large oversaturation with point defects - vacancies appearing in thermal peaks. One fission of uranium atom results in formation of 100000 of point defects. Vacancies, from one side stimulate high stresses needed for transition [4, 5] and from the other - provide anomalously high diffusion and high solubility of molybdenum in gammaphase [17].

The fact of homogenization of U-Mo alloy $[6,7]$ is not something extraordinary. For example, in Ti, phase transformation takes place from tetragonal beta-phase into high-temperature alpha phase (BBC) and molybdenum results in sharp decrease of transformation start temperature on several hundreds degrees, that is in complication of phase transition. Authors of [18] showed that this effect is connected with the increase of localization (concentration level) of valence electrons (LLVE) in the system Me-add-mixture (Mo). At this the LLVE of Mo significantly higher than that of $\mathrm{Ti}$, If alloying is performed by another element, which does not have significant advantage over $\mathrm{Ti}$ on LLVE, for example $\mathrm{Zr}$, no significant decrease of temperature of martensite phase transition (that is complication of transition) is observed.

The same difference in the influence effects of Mo and $\mathrm{Zr}$ is observed in uranium. Unlike $\mathrm{Mo}, \mathrm{Zr}$ changes the uranium lattice when cooling (tempering) not remaining it in high-temperature gamma-phase [8]. This proves that not only in titanium but also in uranium the effect of molybdenum influence (except influence on diffusion) can be connected also with influence of localized (valence) electrons on formation of atomic bonding and stabilization of crystal lattice.

Such approach (to uranium as transition materials) corresponds to then results of recent paper [19] in which group of actinoides-5f $\left(\mathrm{Pa}^{91}-\mathrm{No}^{102}\right)$ is considered as transition metals. By means of quantum-mechanical methods authors demonstrated that in chemical compounds with metals there can appear in uranium short $6 \mathrm{~d}-6 \mathrm{~d}$ covalent bonds of neighbor ions. That can disturb $5 \mathrm{f}-6 \mathrm{~d}$ balance of separate uranium ion, as a result of which fluctuations of chemical bond take place. They increase the density of $6 \mathrm{~d}$ electrons due to destabilization of 5f-shell. Destabilization of electron structure of uranium ion is connected with hybridization $5 \mathrm{f}-6 \mathrm{~d}$. Jumps of external $5 \mathrm{f}$ electrons on $6 \mathrm{~d}$ level due to excitation of fluctuations of chemical covalent bonds with growth of temperature can result in phase $\alpha \rightarrow \beta \rightarrow \gamma$ transitions. Formation of "short" U-U-bonds in the process of uranium alloying with molybdenum was shown in paper [20] by method of mathematical modeling.

In uranium, in conditions of transition, anomalously high self-diffusion is observed. It connected with the fact that enthalpy of migrations decreases almost to zero, when conditions of stability of crystal lattice to uniform deformation $\left(\sigma<\mathrm{C}_{11}-\mathrm{C}_{12}\right)$ no longer works. At this, the energy of vacancies formation becomes lower than one electron-volt, is significantly lower the table data [17]. 
We can see the following picture of the process of homogenization under irradiation of uraniummolybdenum alloy, when swelling (clustering of point defects) does not exist yet.

Large (in comparison with irradiation of nonfissionable in reactors) speed of formation of point defects (one displacement on atom corresponds to burn out $0.001 \%$ ) under uranium fission creates their exclusively high oversaturation in the matrix: this results in two effects.

1. According to paper [21] under these conditions of irradiation increase of parameter of crystal lattice takes place in matrix and correspondingly internal tensile stresses appear which can reach the meanings more that $1 \mathrm{GPa}$. These stresses stimulate flow of direct alpha-beta-gamma transition which flows according to the demands of thermal-dynamics (increase of volume under increase of temperature). Thus appears the gamma-phase. Let's compare the stresses on diagram (see Fig. 4) with stresses caused be defects under neutron irradiation. According to data of R. Stoller from Oak-Ridge National Laboratory, USA under irradiation in water-water energy reactors of reactor vessel steel (97\% of iron) already under doses less that 0.1 and irradiation temperature not more than $100{ }^{\circ} \mathrm{C}$ the level of oversaturation with vacancies $C_{\mathrm{v}} / C^{0}{ }_{\mathrm{v}}$ constitutes about $10^{4}$ times [22]. According to formula, derived for determination of chemcical potential of vacancies, the corresponding values of stresses

$$
\sigma=k T / \Omega \ln \left(C_{\mathrm{v}} / C_{\mathrm{v}}^{0}\right),
$$

(where $k, T, \Omega-$ correspondingly the Boltzmann constant, irradiation temperature, atomic volume of iron $1.18 \cdot 10^{-23} \mathrm{~cm}^{-3}$ ) caused by vacancies should constitute not less than $700 \mathrm{~kg} / \mathrm{mm}^{2}$, which on the value order corresponds to the used by us meanings of stresses on the left axis of diagram Fig. 4.

2. Presence of such oversaturation is similar to that the material temperature is very high, corresponding to the area of existence of high-temperature gamma-phase, in which solubility of molybdenum can reach $20 \%$ [9].

\section{CONCLUSIONS}

1. According to MFDMT hysteresis loop was constructed for phase transitions in pure uranium. It was shown that despite significant changes from the process of martensite formation in pure iron, the martensite transitions in uranium are realized similar to the loop constructed for pure iron.

2. It was shown that tetragonality of BCT-structure ( $\beta$-phase) are less than one, and atoms displacement angle during the phase transformation of lattice are changed in the ranges from 35.25 до $25.88^{\circ}$. Calculated meaning of structure tetragonality $(c / a)$ corresponds to 0.577 , which significantly differs from the case with iron (tetragonality is more than one) and corresponds to experimental meanings.

3. Isolation of martensite crystal takes place with appearance of more solid orthorhombic phase. But the process takes place during cooling which does not result either in cracking or in cavitation.

4. Alloying of uranium with molybdenum assists in stabilization of BBC-structure and process of homogenization under influence of irradiation of particles of nuclear decay does not allow development of processes of ordering and formation of phase $\mathrm{U}_{2} \mathrm{Mo}$. As a result, processes of ordering with further isolation of ordered phase (similar to steels), cannot become the reason of cracking or swelling. Effect of molybdenum influence (except influence on diffusion) can also be connected with influence of localized (valence) electrons on formation of inter-atomic bonding and stabilization of crystal lattice.

5. In the same way, as it occurs in alloy Fe-C (carbon in iron - interstitial impurity), decrease of transformation temperature and decrease of specific volume of transformation with growth of alloying element take place in the system U-Mo.

6. Homogenization can be caused by large oversaturation with point defects taking place in thermal peaks. This can result in two effects.

- High internal tensile stresses appear which stimulates flowing of direct alpha-beta-gamma transition, which flows according to the demands of thermal-dynamics (increase of volume with the increase of temperature). Thus appears the gamma-phase.

- Presence of such oversaturation is similar to that the temperature of the materials is very high, corresponding to the area of existence of hightemperature gamma-phase, in which solubility of molybdenum can reach $20 \%$.

\section{REFERENCES}

1. И.М. Карнаухов, Б.В. Борц, А.Ю. Зелинский, А.О. Мыцыков, И.В. Ушаков, Й. Гохар, И. Большинский, Я.Л. Чи, С.Л. Пэй. Источник нейтронов ННЦ ХФТИ // ВАНТ. 2012, №3(79), c. 3-20.

2. Van den Berghe, P. Lemoine. Review of 15 year high-density low enriched UMo dispersion fuel development for research reactors in Europe // Nucl. Eng. Technol. 2014, v. 46(2), p. 125-146.

3. M.A. Steiner, E. Garlea, J. Creasy, A. de Mint, S.R. Agnew. Temperature dependent elastic properties of $\Upsilon$-phase U-8\%Mo // Journal of Nuclear Materials. 2018, v. 500, p. 184-191.

4. И.Н. Лаптев, А.А. Пархоменко. Метод фазовых диаграмм мартенситных превращений // УФМ. 2010, т. 11 , в. 1 , с. $19-50$.

5. І.М. Лаптев, О.О. Пархоменко. Вакансї, мартенситні перетворення і ресурс ядерних реакторів. Харків: Вид.-во ХНУ ім. В.Н. Каразіна, 2018, 170 с.

6. S.T. Konobeevsky, N.F. Pravdyuk, V.I. Kutaitsev. Effect of irradiation on structure and properties of fissionable materials // Int. Geneve Conferance on the Peaceful Uses of Atomic Energy, United Nations. 1956, v. 7, p. 433-440.

7. M.L. Bleiberg. Phases changes in pile-irradiated Uranium-base alloys // J. Appl. Phys. 1956, v. 27, p. 1270 .

8. H. Zang, D. Yun, K. Mo, K. Wang // Journal of Nuclear Materials. 2017, v. 494, p. 165-171.

9. Коллективная монография. Диаграммы состояния и фазовые превращения сплавов урана. М.: «Наука», 1972, 254 с. 
10. M.A. Steiner, C.A. Calhoun, R.W. Klein, K. An, E. Garlea, S.R. Agnew. Phase transformation kinetics of U-8\% Mo established by in situ neutron diffraction // Journal of Nuclear Materials. 2018, v. 500, p. 184-191.

11. J. Gan, B.D. Miller, D.D. Keiser, et al. Irradiated microstructure of U-10\% Mo monolithic fuel plate at very high fission density // Journal of Nuclear Materials. 2017, v. 492, p. 195-203.

12. М. Гуляев. Металловедение. М.: «Оборонгиз», 1963, 257 с.

13. В.Н. Гриднєв, В.Г. Гаврилюк, І.Я. Дехтяр, Ю.Я. Мешков, П.С. Низін, В.Г. Прокопенко. Ефект Мессбауера в пластично деформованих системах Fe-C // ДАН УРСР. 1975, серія А, №1, с. 75-78.

14. J. Č́́žek, M. Janeček, T. Vlasák, B. Smola, O. Melikhova, R.K. Islamgaliev, and S.V. Dobatkin. The Development of Vacancies during Severe Plastic Deformation // Materials Transactions. 2019, v. 60, N 8, p. 1533-1542.

15. J.E. Gates, E.G. Bodine, J.C. Bell, A.A. Bauer, J.D. Calkins. Stress-strain properties of irradiated U-10 wt.\% Mo: Technical report BMI-APDA-638. Columbus, Ohio, 1958.

16. B.W. Chung, K.E. Lema, P.G. Allen // Journal of Nuclear Materials. 2017, v. 494, p. 165-171.
17. L.N. Kolotova, S.V. Starikov. Atomistic simulation of defect formation and structure transitions in U-Mo alloys in swift heavy ion irradiation // Journal of Nuclear Materials. 2017; doi:10.1016/j.jnucmat.2017.07.044.

18. Г.В. Самсонов, С.М. Браун, П.І. Малько. Про вплив легуючих елементів на температуру поліморфного перетворення титану // ДАН УРСР. 1975, серія А, №3, с. 273-275.

19. А.И. Мицек, В.Н. Пушкарь. Фазовые диаграммы урана и его соединений. 1. Дестабилизация оболочек иона в металле. Квантовая теория // Металлофизика и новейшие технологии. 2019, №3(41), c. 279-288.

20. S.V. Starikov, L.N. Kolotova, A.Yu. Kukshin, D.E. Smirnova, V.I. Tseplyaev. Atomic simulation of cubic and tetragonal phases of U-Mo: Structure and thermodynamic properties // Journal of Nuclear Materials. 2017; doi:10.1016/j.jnucmat.2017.11.047.

21. И.М. Неклюдов, И.Н. Лаптев, А.А. Пархоменко. О влиянии облучения на упругие модули металлических материалов // ВАНT. 2014, №2(90), c. 21-28.

22. R. Stoller. On mobile point defect clusters // Proc. 18-th Int. Symp. "Effects of radiation on materials." ASTM STP 1420. 1998, p. 14-27.

Статья поступила в редакциию 30.10.2019 2.

\section{АНАЛИЗ СТРУКТУРНО-ФАЗОВОЙ СТАБИЛЬНОСТИ U-Мо-МИШЕНИ НЕЙТРОННОГО ИСТОЧНИКА}

\section{Б.В. Бори, И.Н. Лаптев, А.А. Пархоменко, А.Ф. Ванжа, И.А. Воробъев, Ю.А. Марченко}

Проведен анализ структурно-фазовой стабильности топливных материалов с помощью метода фазовых диаграмм мартенситных превращений, предложенного ранее для системы «железо-углерод-вакансии». Показано, что роль молибдена в стабилизации гамма-структуры урана под облучением связана с затруднением фазовых превращений мартенситного типа. Рассмотрена роль точечных дефектов и электронной структуры в процессе гомогенизации структуры сплава под облучением.

\section{АНАЛІЗ СТРУКТУРНО-ФАЗОВОЇ СТАБІЛЬНОСТІ U-Мо-МІШЕНІ НЕЙТРОННОГО ДЖЕРЕЛА}

\section{Б.В. Борц, І.Н. Лаптев, О.О. Пархоменко, О.Ф. Ванжа, І.О. Воробйов, Ю.О. Марченко}

Проведено аналіз структурно-фазової стабільності паливних матеріалів за допомогою методу фазових діаграм мартенситних перетворень, запропонованого раніше для системи «залізо-вуглець-вакансії». Показано, що роль молібдену в стабілізації гамма-структури урану під опроміненням пов'язана 3 утрудненням фазових перетворень мартенситного типу. Розглянуто роль точкових дефектів і електронної структури в процесі гомогенізації структури сплаву під опроміненням. 